\title{
Antioxidant Activity of Phyllanthus niruri Extract, Rutin and Quercetin
}

\author{
Djaja Rusmana ${ }^{1}$, Roro Wahyudianingsih ${ }^{1}$, Mariska Elisabeth ${ }^{1}$, Balqis ${ }^{2}$, Maesaroh ${ }^{2}$, \\ Wahyu Widowati ${ }^{1, *}$ \\ ${ }^{1}$ Faculty of Medicine, Maranatha Christian University, J1. Prof. drg. Suria Sumantri No. 65 Bandung 40164, Indonesia \\ ${ }^{2}$ Biomolecular and Biomedical Research Center, Aretha Medika Utama, Jl. Babakan Jeruk 2 No. 9, Bandung, 40163, Indonesia \\ *Corresponding author. E-mail: wahyu_w60@yahoo.com
}

Received date: Nov 29, 2016; Revised date: Feb 20, 2017; Accepted date: May 3, 2017

\section{Abstract}

ACKGROUND: Normal metabolism of oxygen and exogenous factors constantly generate free radicals which could be harmful to the human body. Human need antioxidants to provide protection against free radicals, thus plants are a good source of natural antioxidants. Phyllanthus niruri (P. niruri) has been known to possess several medicinal properties and contain numerous active phytochemical. In this research, we conducted phytochemical screening and antioxidant assay of $P$. niruri extract along with the compounds rutin and quercetin, which are flavonoids possessing medicinal properties. This study was conducted to determine $P$. niruri, rutin and quercetin as antioxidant.

METHODS: In this study, qualitative phytochemical screening was performed to detect phenol, flavonoid, saponin, tannin, steroid/triterpenoid, terpenoid and alkaloid in $P$. niruri extract. Antioxidant analysis of $P$. niruri, rutin and quercetin was conducted using total measured phenolic content, 2,2-diphenyl-1-picrylhydrazil (DPPH), 2,2'-azinobis-3-ethylbenzo-thiazoline-6-sulfonic acid (ABTS) and ferric reducing antioxidant power (FRAP) assays.

RESULTS: The study revealed that $P$. niruri extract contained saponin, phenol, flavonoid and tannin based on phytochemical screening. In DPPH and ABTS assays quercetin possessed highest antioxidant activity with $\mathrm{IC}_{50}$ value of 0.55 and $1.17 \mu \mathrm{g} / \mathrm{ml}$ respectively. Meanwhile, $P$. niruri extract showed the highest FRAP activity which was $373.95 \mu \mathrm{M} \mathrm{Fe}(\mathrm{II}) / \mu \mathrm{g}$ extract. Rutin possessed the lowest antioxidant activity in all antioxidant assays.

CONCLUSION: This study confirmed that $P$. niruri extract and quercetin have great potential as a natural antioxidant source.

KEYWORDS: asntioxidant, phytochemical, Phyllanthus niruri, quercetin, rutin, free radical

Indones Biomed J. 2017; 9(2): 84-90

\section{Introduction}

Reactive Oxygen Species (ROS) leads to damaging the lipids in the cell membranes, proteins in tissues as well as enzymes, carbohydrates, and DNA to induce oxidation. This oxidative damage may play a causative role in aging and several diseases which are cancer, cardiovascular disease, cataracts, and cognitive dysfunction. $(1,2)$ The high ROS level plays a role in oxidative stress. Therefore, the body requires exogenous antioxidant supply to prevent the oxidative stress.(3)

The dietary antioxidant can be obtained naturally from plants or manufactured synthetically, but most of the natural antioxidants have better antioxidant activity compared with the synthetic one and are considerably safer. $(4,5)$ Various compounds which have antioxidant activity have been isolated from plants, many of them are polyphenols including phenols, phenolic acids, flavonoids, tannins, and lignans.(1) 
Phyllanthus niruri ( $P$. niruri) is one of the herbal medicinal plants that have a broad range of properties, which are antiviral activities against hepatitis B, antimicrobial, hepatoprotective, anticancer, and hypocalcemic agent.(6) Several active phytochemicals have been discovered in $P$. niruri, such as flavonoids, alkaloids, terpenoids, lignans, polyphenols, tannins, coumarins, and saponins.(7) A number of flavonoids had been successfully identified from $P$. niruri, including rutin and quercetin, which are well known to have significant antioxidants and chelating properties.(8-10) In the present study, antioxidant potential of P. niruri was investigated through 2,2'-azinobis-3-ethylbenzo-thiazoline6-sulfonic acid (ABTS), 2,2-diphenyl-1-picrylhydrazil (DPPH) and ferric reducing antioxidant power (FRAP) activity assays and also qualitative phytochemical screening assay with two flavonoid compounds rutin and quercetin for comparison. Protective antioxidant by plant products properties such as $P$. niruri may contribute as therapeutic drugs for free radical induced pathologies.

\section{Methods}

\section{Preparation of $\boldsymbol{P}$. niruri Extract}

The stem and leaves of $P$. niruri were collected from Cianjur, West Java, Indonesia in February 2015. The plants were identified by herbarium staff, Department of Biology, School of Life Science and Technology, Bandung Institute of Technology, Bandung, Indonesia. The stem and leaves of $P$. niruri were mashed, extracted using ethanol $70 \%$ by a maceration method. The ethanol filtrate was filtered every 24 hours and collected until it was colorless. Evaporation was conducted to get concentrated ethanol extract in paste form. The extract was stored at $-20^{\circ} \mathrm{C}$.(11-14)

\section{Qualitative Phytochemical Screening Assay}

The phytochemical assay was conducted on $P$. niruri extract using modified Fransworth method to qualitatively identified the presence of phytochemicals.(12,15-17) Phenol identification: the presence of phenol indicated by green/red/purple/blue or black color. Steroid/triterpenoid identification: the formation of green/blue color indicates the presence of steroid while red/orange sediment indicates the presence of triterpenoid. Saponin identification: saponin content was indicated by persistence of froth on the surface. Tannin identification: purple color formation indicates positive reaction for tannin. Terpenoid identification: terpenoid was indicated by the formation of purple color in the mixture. Flavonoid identification: the presence of flavonoid was shown by the formation of red or orange color. Alkaloid identification: the presence of yellow color indicated the positive result or presence alkaloid.

\section{Total Phenol Content Assay}

Total phenol content was determined using Folin-Ciocalteu reagent.(18) First, $15 \mu \mathrm{L}$ samples were introduced into a 96-well microplate. Subsequently, $75 \mu \mathrm{L}$ of Folin-Ciocalteu reagent $(10 \%)$ and $60 \mu \mathrm{L}$ of sodium carbonate $(7.5 \%)$ were added. The plate was shaken and incubated at $50^{\circ} \mathrm{C}$ for 10 mins. Finally, absorbance value was measured using a microplate reader at the wavelengths of $760 \mathrm{~nm}$. The total phenol content was expressed as Gallic Acid equivalent (GAE), Quercetin equivalent (QE), and Rutin equivalent (RE) using the following formula:

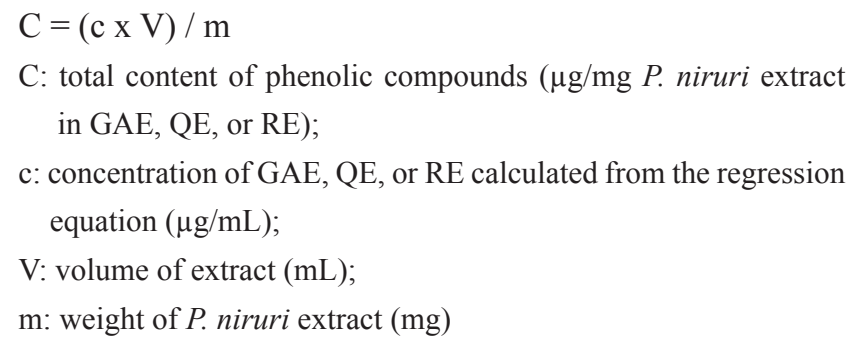

\section{DPPH Assay}

Briefly, $50 \mu \mathrm{L}$ of samples were added to each well in a 96well microplate. Then it was followed by adding $200 \mu \mathrm{L}$ of DPPH (D9132, Sigma-Aldrich, St. Louis, MO, USA) solution $(0.077 \mathrm{mmol} / \mathrm{L}$ in methanol $)$ into the well. The mixture then was incubated in the dark for 30 mins at room temperature. Afterward, the absorbance was read using a microplate reader at $517 \mathrm{~nm} .(11,12,19,20)$ The radical scavenging activity was measured with following formula:

Scavenging $\%=($ Ac - As $) /$ Ac x 100

Ac: negative control absorbance (without sample)

As: sample absorbance

\section{ABTS-reducing Activity Assay}

ABTS solution was produced by reacting $14 \mathrm{mM} \mathrm{ABTS}$ (A1888, Sigma-Aldrich, St. Louis, MO, USA) and $4.9 \mathrm{mM}$ calcium persulfate (1:1 volume ratio) for 16 hours in dark condition at room temperature, then the mixture was diluted with phosphate-buffered saline (PBS) $(\mathrm{pH} 7.4)$ until the absorbance of the solution was $0.70 \pm 0.02$ at wavelengths $745 \mathrm{~nm}$. In brief, $2 \mu \mathrm{L}$ of samples were added to each well at 96-well microplate, then fresh $198 \mu \mathrm{L}$ ABTS solution were added. The absorbance was measured at $745 \mathrm{~nm}$ after the plate had been incubated for $6 \mathrm{~min}$ at $30^{\circ} \mathrm{C}$. The percentage 
inhibition of ABTS radical (\%) was determined by the ratio of reducing of ABTS absorbance in the presence of the sample relative to the absorbance in the absence of the sample (negative control).(12,18) The median inhibitory concentration $\left(\mathrm{IC}_{50}\right)$ were also calculated.

\section{FRAP Assay}

The FRAP reagent was prepared freshly by mixing $10 \mathrm{~mL}$ of $300 \mathrm{mM}$ acetate buffer (pH 3.6 adjusted with the addition of acetic acid) and $1 \mathrm{~mL}$ of $20 \mathrm{mM}$ ferric chloride hexahydrate (Merck 1.03943.0250), and $1 \mathrm{~mL}$ of $10 \mathrm{mM}$ 2,4,6-Tris(2-pyridyl)-s-triazine (TPTZ) (T1253, SigmaAldrich, St. Louis, MO, USA). In 96-well microplate, 7.5 $\mu \mathrm{L}$ of samples were mixed with $142.5 \mu \mathrm{L}$ FRAP reagent then incubated for $30 \mathrm{~min}$ at $37^{\circ} \mathrm{C}$. The absorbance value was measured at $593 \mathrm{~nm}$ with a microplate reader (Thermo Scientific Multiscan GO, Thermo Fisher Scientific, Ratastie, Finland).(12,18,19)

\section{Statistical Analysis}

Each experiment was conducted in a triplicate manner. Data were expressed as a mean \pm standard deviation. The differences between groups were statistically analyzed using one-way analysis of variance (one way ANOVA) with SPSS Statistics version 17.0 software. The probability values of $p<0.05$ were considered as statistically significant using Duncan's post hoc test.

\section{Results}

\section{Phytochemical Screening of $\boldsymbol{P}$. niruri Extract}

The qualitative phytochemical screening assay on $P$. niruri extract showed that the extract had a high content of saponins $(+++)$, a moderate content of phenols, flavonoids, and tannins (++). It also had a low content of steroids, but triterpenoids, terpenoids, and alkaloids were not detected in the screening (-) (Table 1).

\section{Total Phenol Content (TPC)}

The total phenolic content of $P$. niruri extract was measured using GAE, QE and RE as standard. Total phenol content of $P$. niruri extracts has value $61.36 \pm 0.42 \mu \mathrm{g}$ GAE $/ \mathrm{mg}$ extract, $54.72 \pm 0.39 \mu \mathrm{g} \mathrm{QE} / \mathrm{mg}$ extract) and $424.29 \pm 2.96$ $\mu \mathrm{g} \mathrm{RE} / \mathrm{mg}$ extract. Those compounds were used since both are phenolic compounds that are known to be found in $P$. niruri. $(7,17)$ The result revealed that total phenol content of $P$. niruri extract was high, and the highest value was achieved by rutin as standard.
Table 1. Qualitative phytochemical screening results of $P$. niruri extract.

\begin{tabular}{lc}
\hline \multicolumn{1}{c}{ Phytochemical content } & P. niruri extract \\
\hline Phenols & ++ \\
Steroids/ Triterpenoids & $+/$ \\
Terpenoids & - \\
Saponins & +++ \\
Flavonoids & ++ \\
Tannins & ++ \\
Alkaloids & - \\
\hline++++ (very high content); ++ (high content); ++ (moderate content);
\end{tabular}

+ (less content); - (not detected)

\section{DPPH Scavenging Activity}

The scavenging activity was increased along with the increase of the concentration of sample used. It can be seen at the highest concentration among samples, quercetin exhibited the highest DPPH scavenging activity, followed by P. niruri extract and the lowest was rutin (Table 2).

Quercetin had the lowest $\mathrm{IC}_{50}$ value followed by $P$. niruri extract then rutin (Table 3 ). The low $\mathrm{IC}_{50}$ suggested a high antioxidant activity, therefore quercetin has the most effective antioxidant activity in this DPPH assay.

\section{ABTS-reducing Activity}

Among the samples, it can be seen that both $P$. niruri extract and quercetin possess great ABTS-reducing activity, with the highest value in $P$. niruri extract and quercetin were similar and statistically not significant. Rutin had the lowest ABTS-reducing activities among three samples (Table 4). The value of $\mathrm{IC}_{50}$ of $P$. niruri extract, rutin, and quercetin in reducing the ABTS free radical in Table 5 revealed that P. niruri extract have low value of $\mathrm{IC}_{50}$, even though the value was still slightly higher than quercetin. This assured that $P$. niruri extract exhibited effective antioxidant activity but still behind quercetin. Rutin was seen to have high $\mathrm{IC}_{50}$, indicating this compound was not effective in reducing the ABTS radical.

\section{FRAP Activity}

The FRAP activity in this study showed that the activity was increased significantly in a concentration-dependent manner (Table 6). Both P. niruri and quercetin expressed high FRAP activity which indicates great antioxidant capability, while rutin remained to show the lowest activity. At low concentration, quercetin showed higher FRAP activity than $P$. niruri, but at the highest concentration, FRAP activity of P. niruri was comparable to quercetin. 
Table 2. DPPH scavenging activity of $P$. niruri extract, rutin, and quercetin.

\begin{tabular}{cccc}
\hline \multirow{2}{*}{$\begin{array}{c}\text { Concentration } \\
(\boldsymbol{\mu} \mathrm{g} / \mathrm{ml})\end{array}$} & \multicolumn{3}{c}{ DPPH Scavenging Activity (\%) } \\
\cline { 2 - 4 } & $\boldsymbol{P}$. niruri extract & Rutin & Quercetin \\
\hline 0.078 & $17.94 \pm 0.07^{\mathrm{aB}}$ & $12.85 \pm 0.22^{\mathrm{aA}}$ & $20.96 \pm 0.54^{\mathrm{aC}}$ \\
0.156 & $18.37 \pm 0.14^{\mathrm{aB}}$ & $15.05 \pm 0.32^{\mathrm{bA}}$ & $25.20 \pm 0.87^{\mathrm{bC}}$ \\
0.313 & $18.74 \pm 0.40^{\mathrm{aB}}$ & $16.85 \pm 0.18^{\mathrm{cA}}$ & $37.59 \pm 0.58^{\mathrm{cC}}$ \\
0.625 & $22.64 \pm 2.29^{\mathrm{bB}}$ & $17.60 \pm 0.17^{\mathrm{cA}}$ & $59.43 \pm 0.37^{\mathrm{dC}}$ \\
1.25 & $30.96 \pm 0.12^{\mathrm{cB}}$ & $20.78 \pm 0.35^{\mathrm{dA}}$ & $87.54 \pm 0.06^{\mathrm{eC}}$ \\
2.5 & $39.41 \pm 0.87^{\mathrm{dB}}$ & $32.83 \pm 0.82^{\mathrm{eA}}$ & $88.01 \pm 0.35^{\mathrm{efC}}$ \\
5 & $65.72 \pm 2.34^{\mathrm{eB}}$ & $1.86 \pm 0.69^{\mathrm{fA}}$ & $88.77 \pm 0.45^{\mathrm{fgC}}$ \\
10 & $85.54 \pm 0.34^{\mathrm{fB}}$ & $75.40 \pm 0.33^{\mathrm{gA}}$ & $89.16 \pm 0.80^{\mathrm{gC}}$ \\
\hline
\end{tabular}

*The data was presented as mean \pm standard deviation. Different superscript small letters in the same column (among concentrations of the samples) and capital letters in the same row (among samples in various concentration) indicate significance at $p<0.05$ (Duncan post hoc test).

Table 3. IC $_{50}$ DPPH scavenging activity of $P$. niruri extract, rutin, and quercetin.

\begin{tabular}{ccccc}
\hline Samples & Linear equation & $\mathbf{R}^{2}$ & $\begin{array}{c}\mathbf{I C}_{\mathbf{5 0}} \\
(\boldsymbol{\mu g} / \mathbf{m l})\end{array}$ & $\begin{array}{c}\text { Average } \mathbf{I C}_{\mathbf{5 0}} \\
(\boldsymbol{\mu g} / \mathbf{m l})\end{array}$ \\
\hline \multirow{3}{*}{ P. niruri extract } & $\mathrm{y}=7.1691 \mathrm{x}+19.562$ & 0.96 & 4.25 & \\
& $\mathrm{y}=7.0874 \mathrm{x}+19.884$ & 0.96 & 4.25 & $4.24 \pm 0.02$ \\
& $\mathrm{y}=7.3017 \mathrm{x}+19.203$ & 0.95 & 4.22 & \\
\hline \multirow{2}{*}{ Rutin } & $\mathrm{y}=6.4588 \mathrm{x}+14.465$ & 0.98 & 5.5 & \\
& $\mathrm{y}=6.3406 \mathrm{x}+14.532$ & 0.99 & 5.59 & \\
\hline \multirow{2}{*}{ Quercetin } & $\mathrm{y}=6.3814 \mathrm{x}+14.442$ & 0.99 & 5.57 & \\
& $\mathrm{y}=57.638 \mathrm{x}+18.201$ & 0.98 & 0.55 & \\
& $\mathrm{y}=57.3 \mathrm{x}+18.453$ & 0.99 & 0.55 & \\
\hline
\end{tabular}

*The data was presented as mean \pm standard deviation of $\mathrm{IC}_{50}$, The most active DPPH scavenging activity was quercetin with the lowest value of $\mathrm{IC}_{50}$

Table 4. ABTS-reducing activity of $P$. niruri extract, rutin, and quercetin.

\begin{tabular}{cccc}
\hline \multirow{2}{*}{$\begin{array}{c}\text { Concentration } \\
(\mu \mathrm{g} / \mathrm{ml})\end{array}$} & \multicolumn{3}{c}{ ABTS-reducing Activity (\%) } \\
\cline { 2 - 4 } 0.16 & $5.31 \pm 0.49^{\mathrm{aB}}$ & $-0.30 \pm 0.11^{\mathrm{aA}}$ & $7.72 \pm 1.55^{\mathrm{aC}}$ \\
0.31 & $13.17 \pm 0.56^{\mathrm{bB}}$ & $0.33 \pm 0.18 \mathrm{a}^{\mathrm{bA}}$ & $17.86 \pm 0.89^{\mathrm{bC}}$ \\
0.63 & $26.06 \pm 1.16^{\mathrm{cB}}$ & $0.78 \pm 0.06^{\mathrm{bA}}$ & $32.59 \pm 2.13^{\mathrm{cC}}$ \\
1.25 & $45.56 \pm 1.45^{\mathrm{dB}}$ & $1.81 \pm 0.26^{\mathrm{cA}}$ & $60.60 \pm 1.22^{\mathrm{dC}}$ \\
2.5 & $76.18 \pm 2.06^{\mathrm{eB}}$ & $7.94 \pm 0.66^{\mathrm{dA}}$ & $94.93 \pm 0.71^{\mathrm{eC}}$ \\
5 & $98.76 \pm 0.22^{\mathrm{fB}}$ & $12.76 \pm 0.60^{\mathrm{eA}}$ & $99.55 \pm 0.12^{\mathrm{fC}}$ \\
10 & $99.10 \pm 0.29^{\mathrm{fB}}$ & $29.08 \pm 0.65^{\mathrm{fA}}$ & $99.55 \pm 0.24^{\mathrm{fB}}$ \\
\hline
\end{tabular}

*The data was presented as mean \pm standard deviation. Different supers cript small letters in the same column (among concentrations of the samples) and capital letters in the same row (among samples in various concentration) indicate significance at $p<0.05$ (Duncan post hoc test). 
Table 5. IC $_{50}$ ABTS-reducing activity of $P$. niruri extract, rutin, and quercetin.

\begin{tabular}{ccccc}
\hline Samples & Linear equation & $\mathbf{R}^{2}$ & $\begin{array}{c}\mathbf{I C}_{\mathbf{5 0}} \\
(\boldsymbol{\mu g} / \mathbf{m l})\end{array}$ & $\begin{array}{c}\text { Average } \mathbf{I C}_{\mathbf{5 0}} \\
(\boldsymbol{\mu g} / \mathbf{m l})\end{array}$ \\
\hline \multirow{2}{*}{$\begin{array}{c}\text { niruri extract } \\
\mathrm{y}\end{array}$} & $\mathrm{y}=30.224 \mathrm{x}+4.7132$ & 0.99 & 1.5 & \\
& $\mathrm{y}=30.053 \mathrm{x}+3.4504$ & 0.99 & 1.55 & $1.53 \pm 0.03$ \\
\hline \multirow{2}{*}{ Rutin } & $\mathrm{y}=2.9161 \mathrm{x}-0.8221$ & 0.99 & 17.43 & \\
& $\mathrm{y}=2.996 \mathrm{x}-1.1215$ & 0.99 & 17.06 & $17.16 \pm 0.23$ \\
\hline \multirow{3}{*}{ Quercetin } & $\mathrm{y}=2.9908 \mathrm{x}-0.8332$ & 0.99 & 17 & \\
& $\mathrm{y}=36.897 \mathrm{x}+6.4942$ & 0.98 & 1.18 & $1.17 \pm 0.02$ \\
\hline
\end{tabular}

*The data was presented as mean \pm standard deviation of $\mathrm{IC}_{50}$, The most active DPPH scavenging activity was quercetin with the lowest value of $\mathrm{IC}_{50}$

Table 6. FRAP activity of P. niruri extract, rutin, and quercetin.

\begin{tabular}{lccc}
\hline \multirow{2}{*}{$\begin{array}{c}\text { Concentration } \\
(\boldsymbol{\mu} \mathbf{g} / \mathbf{m l})\end{array}$} & \multicolumn{3}{c}{ FRAP activity $(\boldsymbol{\mu M}$ Fe(II)/ $\boldsymbol{\mu g}$ extract) } \\
\cline { 2 - 4 } & $\boldsymbol{P}$. niruri extract & Rutin & Quercetin \\
\hline 0.78 & $72.58 \pm 0.83^{\mathrm{aB}}$ & $18.95 \pm 1.82^{\mathrm{aA}}$ & $116.79 \pm 6.90^{\mathrm{aC}}$ \\
1.56 & $123.92 \pm 0.40^{\mathrm{bB}}$ & $23.65 \pm 0.39^{\mathrm{bA}}$ & $211.50 \pm 1.73^{\mathrm{bC}}$ \\
3.13 & $213.44 \pm 1.78^{\mathrm{cB}}$ & $31.85 \pm 0.46^{\mathrm{cA}}$ & $316.99 \pm 5.28^{\mathrm{cC}}$ \\
6.25 & $303.53 \pm 1.79^{\mathrm{dB}}$ & $53.19 \pm 2.20^{\mathrm{dA}}$ & $348.86 \pm 4.73^{\mathrm{dC}}$ \\
12.5 & $358.49 \pm 3.16^{\mathrm{eB}}$ & $100.58 \pm 1.46^{\mathrm{eA}}$ & $369.11 \pm 5.28^{\mathrm{eC}}$ \\
25 & $373.95 \pm 2.87^{\mathrm{fB}}$ & $189.13 \pm 2.75^{\mathrm{fA}}$ & $372.28 \pm 0.32^{\mathrm{eB}}$ \\
\hline $\begin{array}{l}\text { *The data was presented as mean } \pm \text { standard deviation. Different superscript small letters } \\
\text { in the same column (among concentrations of the samples) and capital letters in the same } \\
\text { row (among samples in various concentration) indicate significance at } p<0.05 \text { (Duncan }\end{array}$ \\
post hoc test).
\end{tabular}

\section{Discussion}

The qualitative phytochemical screening of $P$. niruri extract showed the presence of high content of saponin, the moderate content of phenol, flavonoid, tannin and low content of steroid. However, triterpenoid, terpenoid, and alkaloid were undetected in the extract with the method used in this study (Table 1). Based on other studies, $P$. niruri contains tannins, terpenes, flavonoids, alkaloids, and saponins found in the leaves, stem, and roots of the plant.(7) Calixto, et al., reported that $P$. niruri contained flavonoid quercetin, quercitrin, isoquercitrin, astragalin, rutin and physetinglucoside.(21) Geraniin, repandusinic acid and corilagin are tannins found in P. niruri.(7) The alkaloid isolated from $P$. niruri is a securinega-type alkaloid, epibubbialine.(22) The free radical scavenging activity of this plant could be due to the presence of various bioactive compounds such as alkaloids, flavonoids, and polyphenols has antioxidant capabilities.(23)

The antioxidant assay of $P$. niruri extract, rutin and quercetin revealed that quercetin possessed the greatest antioxidant activity, followed closely by $P$. niruri extract in DPPH and ABTS assay (Table 2, 3). In FRAP assay, P. niruri has the highest activity at the concentration of $25 \mu \mathrm{g} / \mathrm{mL}$, that comparable to quercetin. The differences of antioxidant value among assays indicate that each assay determines different aspects in measuring antioxidant capacity and distinct radicals and mechanisms of reaction occurred. (24) Rutin exhibited the lowest activity among the samples in DPPH (Table 2, 3), ABTS (Table 4, 5), and FRAP assay (Table 6) based on the result, suggesting that rutin has the least antioxidant potential.

The high antioxidant activity of $P$. niruri might be related to the numerous active compounds in the plant, including the phytochemicals flavonoids and 
polyphenols.(25) This was in accordance with the current phytochemical screening results, which detected different phytochemical contents. Based on the total phenol content assay in this study, it was also revealed that $P$. niruri contained high phenol content and the highest total phenol content was obtained using rutin as equivalent, with the value of TPC was $424.29 \mu \mathrm{g} \mathrm{RE} / \mathrm{mg}$ extract. The $\mathrm{OH}$ groups in phenols related to antioxidant activity, that can reduce of amount oxidation by transferring an $\mathrm{H}$ atom to chaincarrying radicals.(26)

Mediani, et al., reported that $P$. niruri contained a high amount of rutin, followed by gallic acid, quercetin.(27) The phenolic compound gallic acid and ellagic acid found in P. niruri have been demonstrated to possess antioxidant activity and cancer chemopreventive abilities.(28) Rutin can reduce the risk of arteriosclerosis, anti-inflammatory and vasoactive properties, reduce coronary heart disease, and anticancer properties. $(29,30)$ In another study, quercetin has scavenging radicals activity and chelating transition metal ions that play a role in preventing oxidation of low-density lipoproteins (LDL) to against cancer, atherosclerosis, and inflammation.(31-33)

In the present study, rutin has the lower antioxidant activity than quercetin. These were consistent with Ahmeda, et al., who reported that quercetin has higher antioxidant activity than rutin in the DPPH assay due to the steric hindrance in rutin. $(34,35)$ In another study conducted by Firuzi, et al., it was also demonstrated that quercetin had significantly higher antioxidant activity than rutin in FRAP assay, with FRAP value after 4 min of quercetin and rutin were 65.0 and $21.9 \mu \mathrm{M}$, respectively.(36)

Those results were assumed to be caused by the absence of 2,3-double bond or 3-OH in the $\mathrm{C}$ ring in the rutin structure, which were presumably important in determining antioxidant activity.(36) Among polyphenolic compounds, several factors could be responsible for increasing radical scavenging effectiveness. Those factors are including ortho-dihydroxy structure in the B ring, 2,3-double bond in conjugation with a 4-oxo function in the C-ring, hydroxy groups in positions 3 and 5 in the A ring, or the angle between the rings in the compound structure.(37-40)

\section{Conclusion}

In summary, $P$. niruri extract and quercetin have great potential as a natural antioxidant source.

\section{References}

1. Pietta PG. Flavonoids as Antioxidants. J Nat Prod. 2000; 63: 1035-42.

2. Atanassova $\mathrm{M}$, Georgieva $\mathrm{S}$, Ivancheva $\mathrm{K}$. Total phenolic and total flavonoid contents, antioxidant capacity and biological contaminants in medicinal herbs. J Univ Chem Technol Metall. 2011; 46: 81-8.

3. Ames BN, Shigenaga MK, Hagen TM. Oxidants, antioxidants, and the degenerative diseases of aging. Proc Natl Acad Sci. 1993; 90: 7915-22.

4. Krisnaiah D, Sarbatly R, Bono A. Phytochemical antioxidants for health and medicine - A move towards nature. Biotechnol Mol Biol Rev. 2007; 1: 97-104.

5. Moure A, Cruz JM, Franco D, Dominguez JM, Sineiro J, Dominguez $\mathrm{H}$, et al. Natural antioxidants from residual sources. Food Chem. 2001; 72: 145-71.

6. Narendra K, Swathi J, Sowjanya KM, Satya AK. Phyllanthus niruri: a review on its ethno botanical, phytochemical and pharmacological profile. J Pharm Res. 2012; 5: 4681-91.

7. Bagalkotkar G, Sagineedu SR, Saad MS, Stanlas J. Phytochemicals from Phyllanthus niruri Linn. and their pharmacological properties: a review. J Pharm Pharmacol. 2006; 58: 1559-70.

8. Heim KE, Tagliaferro AR, Bobilya DJ. Flavonoid antioxidants: chemistry, metabolism and structure-activity relationships. J Nutr Biochem. 2002; 13: 572-84.

9. Sharma P, Parmar J, Verma P, Sharma P, Goyal PK. Anti-tumor activity of Phyllanthus niruri (a medicinal plant) on chemical-induced skin carcinogenesis in mice. Asian Pac J Cancer Prev. 2009; 10: 108994.

10. Moure A, Cruz JM, Franco D, Dominguez JM, Sineiro J, Dominguez $\mathrm{H}$, et al. Natural antioxidants from residual sources. Food Chem. 2001; 72: 145-71.

11. Widowati W, Wijaya L, Wargasetia TL, Bachtiar I, Yellianty Y, Laksmitawati DR. Antioxidant, anticancer, and apoptosis-inducing effects of Piper extracts in HeLa cells. J Exp Integr Med. 2013a; 3: 225-30.

12. Widowati W, Fauziah N, Herdiman H, Afni M, Afifah E, Kusuma HSW, et al. Antioxidant and anti aging assays of Oryza sativa extracts, vanillin and coumaric acid. J Nat Remed. 2016; 16: 2320-8.

13. Widowati W, Mozef T, Risdian C, Yelliantty Y. Anticancer and free radical scavenging potency of Catharanthus roseus, Dendrophthoe petandra, Piper betle, and Curcuma mangga extracts in breast cancer cell lines. Oxid Antioxid Med Sci. 2013b; 2: 137-42.

14. Laksmitawati DR, Prasanti AP, Larasinta N, Syauta GA, Hilda R, Ramadaniati HU, et al. Anti-Inflammatory potential of gandarusa (Gendarussa vulgaris Nees) and soursoup (Annona muricata L) extracts in LPS stimulated-macrophage cell (RAW264.7). J Nat Remedies. 2016; 16(2): 73-81

15. Widowati $\mathrm{W}$, Ratnawati $\mathrm{H}$, Rusdi $\mathrm{U}$, Winarno $\mathrm{W}$, Imanuel $\mathrm{V}$. Pythochemical assay and antiplatelet activity of fractions of velvet been seeds (Mucuna pruriens). HAYATI Journal Biosci. 2010; 17: 85-90.

16. Bera TK, Chatterjee K, Ghosh D. In-vitro antioxidant properties of the hydro-methanol extract of the seeds of Swietenia mahagoni (L.) Jacq. Biomarkers Genomic Med. 2015; 7: 18-24.

17. Adnyana I, Abuzaid A, Iskandar E, Kurniati N. Pancreatic lipase and a-amylase inhibitory potential of mangosteen (Garcinia mangostana Linn.) pericarp extract. Int J Med Res Health Sci. 2016; 5: 23-8. 
18. Widowati W, Widyanto RM, Husin W, Ratnawati H, Laksmitawati $\mathrm{DR}$, Setiawan B, et al. Green tea extract protects endothelial progenitor cells from oxidative insult through reduction of intracellular reactive oxygen species activity. Iran J Basic Med Sci. 2014; 17: 702-9.

19. Mishra A, Bapat MM, Tilak JC, Devasagayam TPA. Antioxidant activity of Garcinia indica (kokam) and its syrup. Curr Sci. 2006; 91: 90-3.

20. Widowati W, Maesaroh M, Fauziah N, Erawijantari PP, Sandra F. Free radical scavenging and a-/b-glucosidase inhibitory activities of rambutan (Nephelium lappaceum L.) peel extract. Indones Biomed J. 2015; 7:157-62.

21. Calixto B, Adair R, Valdir C, Rosendo AA. A review of the plants of the genus Phyllanthus: Their chemistry, pharmacology, and therapeutic potential. Med Res Rev. 1998; 18: 225-58.

22. Zhou M, Zhu H, Wang K, Wei W, Zhang Y. Isolation and X-ray crystal structure of a securinega-type alkaloid from Phyllanthus niruri Linn. Nat Prod Res. 2012; 26: 762-4.

23. Yu J, Wang L, Walzem RL, Miller EG, Pike LM, Patil BS. Antioxidant activity of citrus limonoids, flavonoids, and coumarins. J Agric Food Chem. 2005; 53: 2009-14.

24. de Oliveira AMF, Pinheiro LS, Pereira CKS, Matias WN, Gomes RA, Chaves OS, et al. Total phenolic content and antioxidant activity of some malvaceae family species. Antioxidants. 2012; 1: 33-43.

25. Giribabu N, Rao PV, Kumar KP, Muniandy S, Rekha SS, Salleh $\mathrm{N}$. Aqueous extract of Phyllanthus niruri leaves displays in vitro antioxidant activity and prevents the elevation of oxidative stress in the kidney of streptozotocin-induced diabetic male rats. EvidenceBased Complementary Altern Med. 2014; 2014: 1-10

26. Foti MC. Antioxidant properties of phenols. J Pharm Pharmacol. 2007; 59: 1637-85.

27. Mediani A, Abas F, Khatib A, Tan CP, Ismail IS, Shaari K, et al. Phytochemical and biological features of Phyllanthus niruri and Phyllanthus urinaria harvested at different growth stages revealed by $1 \mathrm{H}$ NMR-based metabolomics. Ind Crops and Prod. 2015; 77: 602-13.

28. Singh K, Khanna AK, Chander R. Protective effect of ellagic acid on t-butyl hydroperoxide induced lipid peroxidation in isolated rat hepatocytes. Ind J Exp Biol. 1999; 37: 939-43.

29. Zielińska D, Szawara-Nowak D, Zieliński H. Determination of the antioxidant activity of rutin and its contribution to the antioxidant capacity of diversifed buckwheat origin material by updated analytical strategies. Polish J Food Nutr Sci. 2010; 60: 315-21.

30. Webster RP, Gawde MD, Bhattacharya RK. Protective effect ofrutin, a flavonol glycoside, on the carcinogen-induced DNA damage and repair enzymes in rats. Cancer Lett. 1996; 109: 185-91.

31. Egert S, Bosy-Westphal A, Seiberl J, Kurbitz C, Settler U, PlachtaDanielzik S, et al. Quercetin reduces systolic blood pressure and plasma oxidised low-density lipoprotein concentrations in overweight subjects with a high-cardiovascular disease risk phenotype: a double-blinded, placebo-controlled cross-over study. British J Nutr. 2009; 102: 1065-74.

32. Hollman PCH, Katan MB. Absorption, metabolism and health effects of dietary flavonoids in man. Biomed Pharmacother. 1997; 51: 30510.

33. Murota K, Terao J. Antioxidative flavonoid quercetin: implications of its intenstinal absorption and metabolism. Arch Biochem Biophys. 2003; 417: 12-7.

34. Ahmeda A, Hossain MA, Ismail Z. Antioxidant properties of the isolated flavonoids from the medicinal plant Phyllanthus niruri. As J Food Ag-Ind. 2009; 2: 373-81.

35. Yildirim A, Mavi A, Kara A. Determination of antioxidant and antimicrobial activities of Rumex crispus L. extracts. J Agric Food Chem. 2001; 49: 4083-9.

36. Firuzi O, Lacanna A, Petrucci R, Marrosu G, Saso L. Evaluation of the antioxidant activity of flavonoids by "ferric reducing antioxidant power" assay and cyclic voltammetry. Biochimica et Biophysica Acta. 2005; 1721: 174-84.

37. Lopez-Velez M, Martinez-Mertinez F, Valle-Ribes CD. The study of phenolic compounds as natural antioxidants in wine. Crit Rev Food Sci Nutr. 2003; 43: 233-44.

38. Pawlak K, Bylka W, Jazurek B, Matlawska I, Sikorska M, Manikowski $\mathrm{H}$, et al. Antioxidant activity of flavonoids of different polarity, assayed by modified ABTS cation radical decolorization and EPR technique. Acta Biol Crac Ser Bot. 2010; 52: 97-104.

39. Dugas AJ, Castaneda-Acosta J, Bonin GC, Price KL, Fischer NH, Winston GW. Evaluation of total peroxyl radical-scavenging capacity of flavonoids: structure activity relationships. J Nat Prod. 2000; 63: 327-31.

40. Harborne JB, Williams CA. Advances in flavonoid research since 1992. Phytochemi. 2000; 55: 481-504. 